\title{
Lessons learnt from semi-arid wetland degradation. Las Tablas de Daimiel National Park
}

\author{
Héctor Aguilera y Luis Moreno Merino \\ Instituto Geológico y Minero de España IGME. C/ Ríos Rosas 23. 28003 Madrid. \\ h.aguilera@igme.es, I.moreno@igme.es
}

\begin{abstract}
The Tablas de Daimiel National Park wetland developed in an area characterized by the cyclic nature of droughts, excessive aquifer exploitation and an evident aridification trend driven by climate change. The park and its surroundings have been exploited since prehistoric times and they are currently deeply anthropized to the point that both the physical survival of the wetland as well as its ecological function entirely depend on human action. A severe drought between 2006 and 2009 together with the drawdown of the water table caused the dry out of the system, reed overgrowth, disappearance of cut-sedge and sub-aquatic Chara spp. meadows and a smouldering peat fire. During this same period surface water, soil and groundwater were sampled for physical, hydrological and hydrochemical characterization. Upon drainage, the system functions as an artificial recharge system and becomes eutrophic showing large nutrient and salt content in soils and water. High water transmissivity capacities in the unsaturated zone and anthropic park management (soil compacted by heavy machinery, recirculation of low quality groundwater, reed reaping, water transfers, etc.) condition groundwater pollution. Increased knowledge of the physical-environment has allowed us to build a conceptual model of the surface water - groundwater interactions and to develop management tools to support the park management during a system dry out. Amongst these actions, we propose an unsaturated flow model for soil moisture simulation than can be used to predict critical soil water content for reed overgrowth or peat combustion risk.
\end{abstract}

Keywords: semi-arid wetland, groundwater, management, conceptual model, anthropization.

\section{Lecciones aprendidas de la degradación de un humedal semiárido. Parque Nacional de las Tablas de Daimiel}

\author{
RESUMEN
}

El Parque Nacional de Las Tablas de Daimiel se ha desarrollado en una zona caracterizada por la naturaleza cíclica de las sequías, la explotación excesiva del acuífero y una tendencia hacia la aridificación impulsada por el cambio climático. El entorno del parque ha sido explotado desde tiempos prehistóricos y en la actualidad se encuentran profundamente antropizado. Como consecuencia se ha llegado a una situación en la que tanto la supervivencia física del humedal como su función ecológica dependen totalmente de la acción humana. Entre los años 2006 y 2009 una fuerte sequía, junto al descenso de los niveles piezométricos, provocaron la desecación completa del humedal, la invasión del carrizo, la desaparición de la masiega y las praderas de Chara spp., y el incendio de las turberas. Coincidiendo con este periodo se muestrearon suelos y aguas subterráneas y superficiales para su caracterización física, hidrológica e hidroquímica. Durante la desecación, el parque opera como un sistema de recarga artificial y se eutrofiza, presentando una gran abundancia de nutrientes y elevada salinidad en suelos y aguas. La elevada transmisividad de la zona no saturada, y las medidas de gestión (compactación del suelo por maquinaria pesada, recirculación de aguas subterráneas, siega de carrizo, etc.), condicionan la contaminación del agua subterránea. El incremento del conocimiento del medio físico-químico ha permitido desarrollar un modelo conceptual de funcionamiento hidrológico y medidas de apoyo a la gestión en periodos de sequía. Entre éstas destaca un modelo de simulación de la humedad del suelo que permite prever el riesgo de incendio de turbas o de expansión del carrizo.

Palabras clave: humedal semiárido, agua subterránea, gestión, modelo conceptual, antropización. 
Héctor Aguilera y Luis Moreno Merino, 2019. Lessons learnt from semi-arid wetland... Boletín Geológico y Minero, 130 (4): $711-728$

VERSIÓN ABRAVIADA EN CASTELLANO

\section{Introducción}

La antropización de los sistemas naturales es un proceso global que puede considerarse más una regla que una excepción. El Parque Nacional de Las Tabla de Daimiel (TDNP) es un perfecto ejemplo de ello en el que se observan con facilidad los cambios inducidos en el medio biótico y abiótico por el manejo artificial del humedal y la degradación del ecosistema. La antropización se debe a numerosas acciones, como el encauzamiento de los ríos, la construcción de diques, los vertidos de aguas residuales, los drenajes artificiales o el excesivo bombeo del acuífero. A esto se une la irregularidad del clima mediterráneo y el cambio climático hacia una mayor aridez.

La antropización reduce la capacidad tampón de los sistemas naturales, frecuentemente de forma no reversible (Cirujano et al., 2010; Hattermann et al., 2008; Johnston, 1994; Mitsch and Gosselink, 2000). Esto es especialmente cierto en las zonas húmedas donde la idea de restauración al estado original es poco realista y el concepto de "sistema natural" debe ceder paso al de "sistema natural perturbado", que permite definir mucho mejor las estrategias de protección y remediación.

EITDNP es un excelente laboratorio en el que estudiar los efectos de la antropización de un humedal. La degradación se ha debido a una serie de intervenciones a partir de la década de 1980: construcción de presas, bombeos con aguas de mala calidad, trasvases ineficientes, siegas de carrizales, construcción de cortafuegos con maquinaria pesada, etc. Estas medidas produjeron alteraciones hidrológicas e hidroquímicas que conllevaron eutrofización y pérdida de biodiversidad y la alteración de la estructura y propiedades del suelo.

Las prácticas de gestión, más allá de detener la degradación del humedal, han contribuido a su "desnaturalización" y pueden considerarse como causa del impacto antrópico. En este trabajo se exponen las lecciones aprendidas tras más de cuatro años de monitoreo y análisis exhaustivo de aguas y suelos en elTDNP durante el último periodo de desecación (2006-2009). El objetivo principal es realizar una interpretación integrada y práctica de los resultados obtenidos, proponiendo nuevas herramientas de gestión, para evitar repetir errores del pasado frente a nuevos eventos de sequía.

\section{Metodología}

EI PNTD se sitúa en la confluencia de los ríos Cigüela y Guadiana (Fig. 1). El humedal original se formó en el borde del acuífero Mioceno-Plioceno de la Mancha Occidental, constituyendo un área de descarga. Por efecto de la antropización el TDNP ha funcionado como un sistema de recarga de un acuífero local somero, colgado y multicapa, desconectado del flujo regional profundo (Aguilera et al., 2013).

En Aguilera et al. (2016) se definieron tipos funcionales de suelo (SFT) que agrupan los materiales aflorantes con semejantes propiedades hidráulicas (Fig. 2).

Se ha seguido una aproximación integrada dada la complejidad del sistema y la falta de información geológica e hidrogeológica detallada. Los muestreos de suelos y aguas se llevaron a cabo entre 2006 y 2010 (Fig. 2). Los análisis de suelos incluyen extractos en agua, materia orgánica y nutrientes (Aguilera et al., 2011). Los parámetros físicos determinados incluyen textura, densidad real y aparente, conductividad hidráulica saturada, curvas de infiltración, repelencia, y curvas de retención de humedad (Aguilera, 2013; Aguilera et al., 2016). Se han realizado análisis periódicos de la composición química e isotópica del agua subterránea. Se dispone de medidas mensuales del nivel piezométrico y la superficie inundada y se instaló una red de medición de humedad y temperatura el suelo en 12 puntos (Fig. 2).

\section{Resultados y discusión}

Durante los periodos de sequía se incrementa notablemente el transporte de nutrientes hacia la zona saturada y, por tanto, el riesgo de contaminación del agua subterránea y de cualquier ecosistema conectado (Aguilera et al., 2011, 2013). Esto está favorecido por el incremento de permeabilidad del suelo, la evaporación de aguas superficiales, la disolución de sales en suelos salinizados, la entrada de efluentes contaminados y la recirculación de agua subterránea. Se ha observado además una notable acumulación de nutrientes en la capa más superficial del suelo $(0-20 \mathrm{~cm})$. La abundancia de nutrientes en suelos y aguas permite clasificar el TDNP como sistema eutrófico.

La elevada salinidad observada tanto en aguas como en suelos parece estar controlada por procesos litológicos y evaporativos. Los nutrientes tienen origen tanto externo (fósforo, carbono orgánico), a través de aguas superficiales, como interno (nitrato, carbono orgánico), mediante la acumulación de materia orgánica de las plantas y la mineralización de la misma. Los análisis de suelos muestran una clara relación entre el 
Héctor Aguilera y Luis Moreno Merino, 2019. Lessons learnt from semi-arid wetland... Boletín Geológico y Minero, 130 (4): $711-728$

contenido de materia orgánica y nutrientes en profundidad, especialmente fósforo, con la red de drenaje superficial (limos fluviales en zanjones). Esto indica que el aporte ocasional a través de avenidas y trasvases tiene efectos secundarios, representando una fuente de nutrientes para el TDNP. Este fenómeno se ve agravado porque estos limos están conectados directamente con niveles colgados que almacenan el agua subterránea contaminada y la transmiten a las capas profundas.

En cuanto a las propiedades físicas, los SFT orgánicos son los que muestran valores más altos de capacidad de infiltración y conductividad hidráulica saturada (Tabla 1), debido a su estructura menos compacta y a la porosidad secundaria derivada del agrietamiento producido por la desecación. Además, las turbas presentan una fuerte hidrofobicidad. La consecuencia es un incremento de las tasas de infiltración en la margen izquierda delTDNP y aguas abajo de la presa central de varios órdenes de magnitud respecto a las condiciones de encharcamiento (Fig. 1 y Fig. 2).

En sequía, la humedad del suelo determina la combustibilidad de las turbas y la expansión del carrizo. El modelo de flujo en zona no saturada de Aguilera et al. (2016), que simula la evolución de la humedad del suelo, puede ser empleado como herramienta de gestión acompañado de una red de monitorización in situ (Fig. 3). El modelo permite predecir, a partir de información meteorológica básica, las humedades críticas para que el carrizo empiece a invadir o la turba se encuentre en riesgo de combustión. Simulaciones de un escenario de sequía estiman que la humedad crítica para la expansión del carrizo se alcanza tras 9-10 meses de haber desaparecido la lámina de agua, mientras que las turbas son combustibles (50\% probabilidad) al final del periodo de simulación (Aguilera et al., 2016).

En la actualidad, la zona inundable del TDNP está cerrada por un conjunto de represas en los puntos de entrada y salida. Cuando la zona está inundada funciona como un sistema de embalses regulados conectados en serie (Castaño et al., 2012b). Al secarse, el área opera como un sistema de recarga artificial, especialmente en su margen izquierda, mucho más permeable e influenciada por bombeos que la derecha. La gran acumulación de nutrientes y materia orgánica condiciona la contaminación de las aguas subterráneas. Además, las medidas de gestión habituales (compactación del suelo por maquinaria pesada, recirculación de aguas subterráneas de mala calidad, siega de carrizo, trasvases, extinción de incendios) aumentan el riesgo de liberación de nutrientes.

El funcionamiento hidrológico queda recogido en el modelo conceptual de relación aguas superficiales aguas subterráneas de la Figura 4. Este modelo puede servir como base para diseñar las futuras prácticas de gestión del TDNP en sequía y dada la relativa simplicidad de la metodología propuesta es fácilmente trasladable a otras zonas semiáridas en las que se ha desarrollado un humedal ligado a las aguas subterráneas.

\section{Conclusiones}

El manejo artificial del TDNP lo ha convertido en un "humedal antropogénico", completamente dependiente de la intervención humana y cuya alteración es en muchos casos irreversible. Por ejemplo, la falta de continuidad entre la lámina superficial y la zona saturada impide la recuperación real del humedal. Estos efectos se han evidenciado en la falta de recuperación real de biodiversidad tras la "recuperación del humedal" de 2010. Algunos estudios han identificado las especies invasivas y la contaminación química como las principales causas de pérdida de biodiversidad; otros sugieren que la gestión del humedal como un sistema cerrado de represas es la causa de problemas ecológicos como el desarrollo masivo de carpas que impide el desarrollo de las praderas de Chara spp. El cambio climático añade incertidumbre al proceso de rehabilitación.

Los análisis hidrológicos e hidroquímicos muestran que la combinación de la acumulación de materia orgánica y nutrientes en aguas superficiales y suelos, la elevada transmisividad en la zona no saturada de la margen izquierda del TDNP, y las medidas de gestión, condicionan la contaminación del agua subterránea durante los periodos de desecación.

El incremento del conocimiento del medio físico-químico delTDNP ha permitido desarrollar herramientas de gestión en periodo de sequía. La clasificación y cartografía de los SFT ha permitido delimitar áreas de comportamiento similar que permite optimizar el sistema de monitorización. La simulación de la zona no saturada en diferentes escenarios climáticos y de gestión puede, por ejemplo, prever la evolución de la humedad del suelo y con ello el riesgo de incendio de turbas o de expansión del carrizo de forma descontrolada. La gran cantidad de datos físico-químicos disponibles sirven de base para construir herramientas de gestión que permiten analizar el impacto de la sequía o los incendios sobre el medio natural, son una "línea de base" sobre la que determinar el impacto del cambio climático a lo largo del tiempo.

Por último, es necesario aún cuantificar los efectos de los impactos y mejorar el conocimiento sobre las características geológicas, las dinámicas hidrológicas e hidroquímicas en periodos de inundación, así como de las propiedades de las turbas. 


\section{Introduction}

Since the 1960s strong human intervention and disturbance (ditching, damming, pollution, artificial drainage and flooding, etc.) has led to the alteration of the wetland area of the Tablas de Daimiel National Park (TDNP) in central Spain. Mainly due to excessive groundwater pumping for irrigation in the Mancha Plain region coupled to inherent climatic variability in semi-arid Mediterranean environments, the wetland was disconnected from the underlying aquifer system and now suffers from alternating flooding and drainage cycles. This process induces severe impacts and modifications in the ecological characteristics of the wetland, both in the biotic as well as the abiotic environments. From a hydrogeological point of view, the hydraulic gradient has shifted from upwards to downwards, turning the TDNP into a recharge area. The most striking representative of human-induced degradation of the physical-chemical structure of TDNP is the process of peat cracking, subsidence and fire caused by desiccation. Artificial management aiming to sustain flooding conditions has also contributed to system disturbance and degradation turning the wetland into a regulated system of connected reservoirs which operates as an aquifer recharge area during periods of groundwater level depletion.

Anthropization of natural systems is a global phenomenon that has to be considered more the rule rather than the exception. At the beginning of the $21 \mathrm{st}$ century unsustainable development and climate change poses a serious risk not only to the survival of major ecosystems worldwide, but especially to their "natural" existence (Jia and Luo, 2009; Wang et al., 2010). Anthropization often reduces their buffering capacity through modifications of physical, chemical and biological properties which might in turn be irreversible (Cirujano et al., 2010; Hattermann et al., 2008; Johnston, 1994; Litaor et al., 2006; Mitsch and Gosselink, 2000). This is particularly true for wetland areas, where the paradigm framework of wetland restoration to a previously existing state renders more an idealistic approach than a reachable goal (Harvey and McCormick, 2009; Larsen et al., 2007; Martínez-Santos et al., 2008a; Niedermeier and Robinson, 2007; Pfadenhauer and Klötzli, 1996; Zedler and Kercher, 2005).

Despite the different protection attempts to preserve their ecological identity and value, anthropization of earth systems should be seen as an added intrinsic property rather than an external disturbance (Messerli et al., 2000; Moiwo et al., 2010; Sutula et al., 2003; Thiere et al., 2009). Hence, understanding "natural systems" as "disturbed natural systems" becomes a key issue in order to define appropriate management strategies to prevent wetland ecosystems from disappearing (Amezaga and Santamaría, 2000; Harvey and McCormick, 2009; Messerli et al., 2000; Wang et al., 2010). These strategies should be based on realistic conceptual hydrological models which represent current conditions of hydrological behaviour rather than past natural or future desirable situations (Krause et al., 2007; Manzano et al., 2002; Pfadenhauer and Klötzli, 1996; Richter et al., 1996; Rudolph et al., 2005; Sikdar and Sahu, 2009; van Duren and Pegtel, 2000; Zedler, 2000).

The TDNP constitutes a perfect example of anthropization. Degradation led to a series of management interventions from the 1980s that, in turn, generated more impact than repair (Cirujano et al., 2010). As argued by these authors, at the beginning, wetlands management schemes had a narrow target focus (i.e. priority habitat for waterfowl). Therefore, the main goal was to maximize flooded areas for rare and endangered bird species, without taking other wetland functions into account. Management success was evaluated only on the basis of an increase in bird populations and the occurrence of a protected species in censuses. In the TDNP this was exemplified by the Hydrologic Restoration Plan (HRP), which pursued the maintenance of suitable flooding levels for waterfowl through water transfers, groundwater pumping and dam retention.

Water transfers from the Tajo-Segura aqueduct are carried out through the channelized Cigüela River over a distance of $150 \mathrm{~km}$. Derivations started in 1988 and since then they have had an average yield (percentage of volume of water arriving to the TDNP) of approximately $50 \%$, with a minimum of $3.8 \%$ in the transfer of 2009 (data provided by the TDNP Management Authorities). The underlying reason is that, due to bureaucratic issues, they have often been carried out during spring or summer when evaporation and infiltration rates are highest and when increased demands of water for irrigation promote illegal extractions. Flooding with pumped groundwater is a management tool used constantly during dry periods to keep a minimum flooded area. Both management tools induce quantitative and qualitative impacts to the system as will be argued throughout this study.

Due to unsuitable planning and the quality of resources, hydrological and hydrochemical modifications were the main outcome of the HRP. Given the limitation of such a narrow-focused management plan, undesired results of degradation (i.e. biodiversity loss) resulting from other forms of impacts (i.e. eutrophication) also took place. The resulting loss of food resources for birds or the increased frequency of 
Héctor Aguilera y Luis Moreno Merino, 2019. Lessons learnt from semi-arid wetland... Boletín Geológico y Minero, 130 (4): $711-728$

massive bird kills through botulism outbreaks even counteracted the management goals in the long term. Rather than protecting and enhancing waterfowl populations, the results were an impoverishment of the communities and the loss of desired species (Cirujano et al., 2010).

From the mid 2000s, a management focus integrating dynamic ecosystem processes was implemented, based upon global ecosystem studies. What mattered was to restore the wetland physiognomy and to attain the maximal biological diversity, whilst respecting the environmental characteristics of the wetland (Cirujano et al., 2010). However, under this scope, alterations of the abiotic environment are often overlooked.

Actions such as the disposal of sediment and decaying vegetation, particularly reed beds, construction of ditches and fire breaks began to be implemented (Sánchez-Carrillo et al., 2010; Aguilera et al., 2011). These measures involve the use of heavy farm machinery within the TDNP which alters the physical properties of soils as water and solute transmitters.

Anthropic water management can induce a high degree of stochasticity and uncertainty in the hydrological behaviour of the TDNP system due to increased complexity and irregularity (SánchezCarrillo and Álvarez-Cobelas, 2010; Cirujano et al., 2010; Zorrilla et al., 2010). For example, increasing variability of hydroperiods and vegetation management modify macrophyte cover patterns which, in turn, determine the evapotranspiration term of the hydrological balance (Sánchez-Carrillo et al., 2004).

Far from stopping wetland degradation, the management practices have increased the degree of disturbance and significantly contributed to system "denaturalization". Therefore, they can be considered as indicators of anthropic impact on the weakened TDNP system.

Lessons learnt after more than four years of soil and water monitoring in the TDNP are presented and discussed in this paper. Sampling coincided with an intense drought that caused complete wetland desiccation and the highest degree of anthropic impact ever known. The main objective is to make a practical interpretation of what has been learnt so as to keep such an impact from happening again. Specifically, we analyse the main alterations of the soil-water system from a qualitative and quantitative point of view. Environmental and hydrogeological implications of degradation are discussed. Furthermore, we propose original management tools that can optimize TDNP management actions, particularly water transfers and emergency pumps, and minimize the risk of groundwater pollution.

\section{Materials and methods}

\section{Study area description}

The TDNP is located in semi-arid central Spain in the confluence of the Cigüela and Guadiana Rivers $\left(39^{\circ} 09^{\prime} \mathrm{N}, 3^{\circ} 40^{\prime} \mathrm{W}\right.$; Fig. 1). The surface of the TDNP is 3,030 ha of which approximately 1,800 ha are subjected to flooding. The former natural wetland of the TDNP was originated at the outflow boundary of a $15,000 \mathrm{~km}^{2}$ surface water basin and the $5,500 \mathrm{~km}^{2}$ Mancha Occidental groundwater system, in the confluence of the Cigüela and Guadiana Rivers. Average annual precipitation and mean temperature for the period 1904-2011 are $406.8 \mathrm{~mm}$ and $14.6{ }^{\circ} \mathrm{C}$, respectively (Santisteban and Mediavilla, 2012). Potential evapotranspiration is around $850 \mathrm{~mm} \mathrm{yr}^{-1}$ (SánchezCarrillo et al., 2004), exceeding rainfall most of the year.

Further details on the characteristics of the physical environment of the TDNP can be found in the extensive literature referring to this site (ÁlvarezCobelas et al., 2001; García-Hidalgo et al., 1995; Domínguez-Castro et al., 2006, Castaño et al., 2013; Aguilera, 2013).

From a hydrogeological point of view, the TDNP area comprises the edge of the unconfined MiocenePliocene unit of the Mancha Occidental aquifer system, constituted by limestone and marl materials. This aquifer occupies an area over $5,000 \mathrm{~km}^{2}$ with an average thickness of $200 \mathrm{~m}$ (Martínez-Santos et al., 2008b). Heterogeneous vertical and horizontal lithologies (García Rodríguez, 1996), differential karstification and subsidence effects determine varying degrees of interconnection between Tertiary and Quaternary materials conditioning the complex local hydrogeological behaviour of the system (Castaño et al., 2013a, 2013b). With depleted piezometric levels the TDNP wetland operates as a recharge system for a local shallow perched multi-layer aquifer disconnected from the deeper regional groundwater flow towards main irrigation areas (Aguilera et al., 2013). A downward water flux from the perched levels through semi-permeable layers is developed, conditioning a slow delayed recharge of deeper layers. This situation was reverted after the wet period 2010-2014 leading to partial aquifer recovery and groundwater discharge into the TDNP (Castaño et al., 2018; del Pozo and Mejías, 2017).

A previous study led to definition and mapping of soil functional types (SFT) according to their hydraulic properties (Fig. 2, Aguilera et al., 2016). Four main SFT are defined: clay, silt (fluvial deposits in rivers, ditches and drains), organic-rich materials 

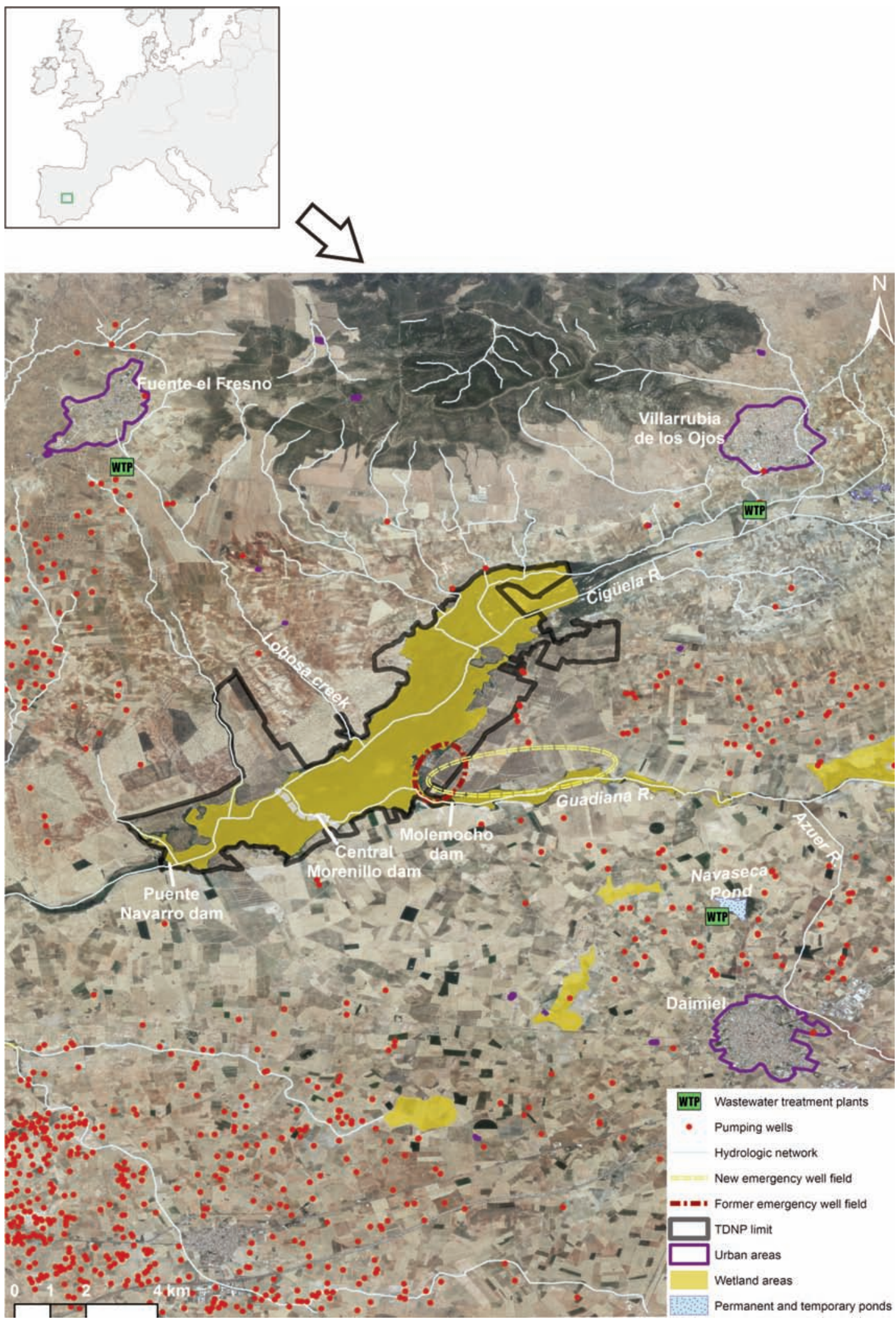

Figure 1. Aerial photograph of the Tablas de Daimiel National Park (TDNP) area. Main impacts such as wastewater discharge points and pumping wells for irrigation are shown. Source: http://centrodedescargas.cnig.es

Figura 1. Mapa de situación del Parque Nacional de Las Tablas de Daimiel (TDNP) y su entorno. Se representan los principales impactos como son puntos de vertido de depuradoras y pozos de bombeo para regadío. Fuente: http://centrodedescargas.cnig.es 
(characterized by high organic matter contents, include peat, peaty silt and other organic soils) and charophyte layers (unconsolidated carbonated sediments biologically produced in sub-aquatic Chara spp. meadows). The physical-chemical properties of the SFT are mainly determined by the parent material but other factors, basically anthropization (drainage, compacting) and edaphization, can be as important or even more important than the former. Therefore, the defined soil units also take into account the degree of alteration and evolution of the materials. The SFT map in Figure 2 represents the general zonal distribution of the dominant materials at the top of the vadose zone (i.e. from soil surface to 1 meter deep).

\section{Data sampling and analysis}

The study follows an integrated methodological approach to deal with system complexity and hetero- geneity, as well as the lack of detailed geological and hydrogeological knowledge. The physical and chemical properties of the surface water-soil-groundwater system were intensively sampled and monitored throughout the last desiccation period (2006-2009). Figure 2 shows the distribution of soil and water sampling points. Soil chemical analyses included mobile solutes in soil-water extracts, and organic matter (OM) and nutrients in the solid matrix (Aguilera et al., 2011). The following soil physical parameters were determined: texture, bulk density, saturated hydraulic conductivity, infiltration curves, water repellency (hydrophobicity), and water retention and hydraulic conductivity curves (Aguilera, 2013; Aguilera et al., 2016). Periodic standard hydrochemical analyses were performed on surface water and groundwater samples, including major and minor cations and anions, as well as stable $\left({ }^{2} \mathrm{H}\right.$ and $\left.{ }^{18} \mathrm{O}\right)$ and radioactive (tritium) isotopes (Aguilera et al., 2013). Groundwater levels were monitored either monthly or bi-yearly. Time series data on monthly flooding surfaces in the

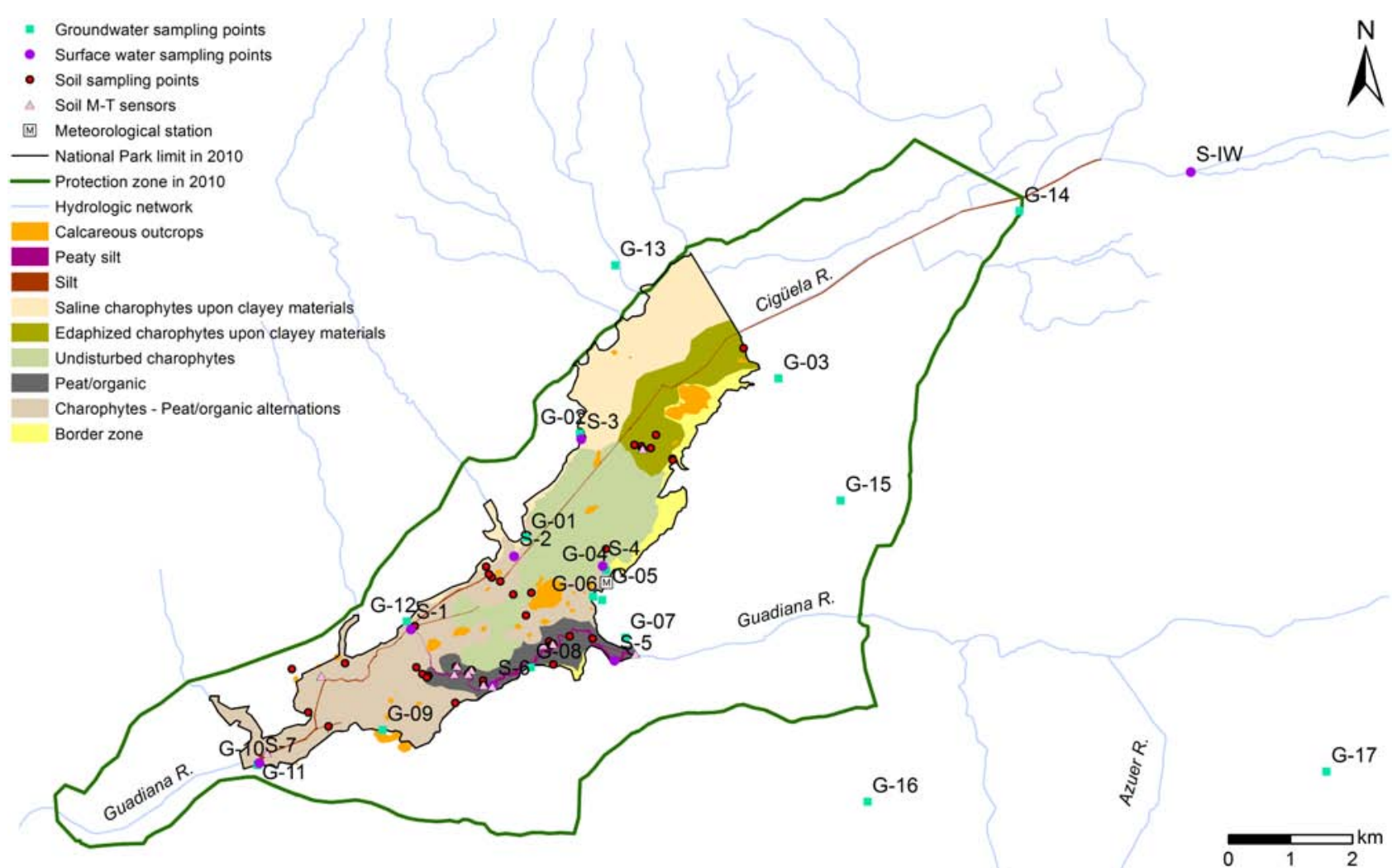

Figure 2. Location of sampling points and distribution of soil functional types in the Tablas de Daimiel National Park (TDNP). The extent of the TDNP and its protection zone correspond to the limits in 2006-2010 when the total TDNP surface was 1,928 ha, two thirds of the current 3,030 ha (Fig. 1). M-T: moisture - temperature.

Figura 2. Localización de los puntos de muestreo y distribución de los tipos funcionales de suelo en el Parque Nacional de Las Tablas de Daimiel (TDNP). Los límites delTDNP y de su zona de protección corresponden a los existentes en el periodo 2006-2010, cuando la superficie total del TDNP era 1928 ha, dos terceras partes de la actuales 3030 ha (Fig. 1). M-T: humedad - temperatura. 
period 1974-2010 and water transfers to the park from the Tagus River in the period $1988-2010$ were provided by the TDNP Management Authorities.

Daily meteorological data was collected from two meteorological stations from the State Meteorological Agency (AEMET), 4112U (1982-2010 series), located inside the TDNP (Fig. 2), and 4121 (1920-2010 series), in the city of Ciudad Real, $25 \mathrm{~km}$ southwest from the TDNP. Furthermore, the TDNP Management Authorities provided a series of 10 minute interval records and daily averages for station $4112 \mathrm{U}$ in the period 2002-2009, including data on wind speed, solar radiation, relative air humidity, accumulated rainfall and maximum and average temperatures.

Finally, soil moisture and temperature was registered continuously from April to November 2009 in 12 points of the TDNP (Moreno et al., 2010; Aguilera, 2013). At each point, two moisture sensors and three temperature sensors were placed on different soil materials at depths between 20 and $60 \mathrm{~cm}$. Throughout 2008 and 2009 field observations on the characteristics of cracks and pipes in shrinking peats such as width, depth and interconnection were annotated. Big hollows of several decimetres thick were often found in the sub-soil.

Further details on sampling and specific methods and analysis can be found in the referred articles.

\section{Results and discussion}

\section{Qualitative aspects}

The chemical analyses of surface water, unsaturated soils and groundwater reported in Aguilera et al. (2011) and Aguilera et al. (2013) show that there is an active downward nutrient transport from inflowing surface water to the groundwater through the vadose zone during drying cycles.

Evaporation, salt dissolution from saline soils, low quality inflows (i.e. wastewater, re-circulating groundwater pumped for artificial flooding) and internal OM loading condition high salinity and solute concentration in ponding water. Extremely high infiltration rates and saturated hydraulic conductivities in dry SFT bring about a strong downward gradient transporting water and solutes through the vadose zone (VZ) towards the groundwater (Aguilera, 2013). A strong nutrient accumulation (absorption) in the topsoil $(0-20 \mathrm{~cm})$ has been observed. Approximate median electrical conductivity, organic carbon, total nitrogen, available phosphorus and leachable nitrate contents in this layer are $4,000 \mu \mathrm{S} \mathrm{cm}^{-1}, 6 \%, 0.5 \%, 20$ $\mathrm{mg} \mathrm{kg}^{-1}$ and $50 \mathrm{mg} \mathrm{l}^{-1}$, respectively (Aguilera et al., 2011). Furthermore, salinity, soil organic carbon and total nitrogen $(\mathrm{N})$ remain quite high in depth.

Nutrients have both external (phosphorus, organic carbon) as well as internal (nitrate, organic carbon) origins. External inputs take place through inflowing surface waters, whereas internal ones mainly come from plant $\mathrm{OM}$ accumulation and mineralization. The hydrochemical interaction between surface water and shallow groundwater through the soil matrix is evidenced by total organic carbon distributions in the outlet area of the Puente Navarro dam (S7 and G-11, Fig. 2; Aguilera et al., 2013) and by infiltration from the Guadiana and Cigüela ditches (Moreno et al., 2013).

On contrary, high salinity in all studied environments appears to be controlled by lithological and evaporative processes. Soil data analysis proves a clear spatial association between soil OM and nutrient content in depth, particularly phosphorus (P), with the surface water drainage network (fluvial silts in riverbeds and ditches). This indicates that occasional flooding through freshets or transfers has sideeffects, representing a primary source of nutrients to TDNP soils. This was confirmed by the hydrochemical analysis of the effluent of the Villarrubia de los Ojos wastewater treatment along the Cigüela ditch (Moreno et al., 2013). Moreover, the fact that the Park is located at the downstream edge of the Upper Guadiana basin, where agricultural practices are quite intense, has to be taken into account. Even though the hydrologic network remains inactive for long periods, occasional water inflows carrying considerable loads of particles from lithological weathering as well as wastewater, agricultural and even industrial spills occur (Moreno et al., 2013; JiménezBallesta et al., 2017). The accumulation of $P$ coming from non-point source pollution in ditches and lower areas is indeed a generalized process in the basins (Reddy and DeLaune, 2008). The implications of these phenomena are magnified because the silty nutrientrich material filling up the ditches gives rise to perched water tables underneath the TDNP as "bank storage" processes (Silvino Castaño, personal communication, 2012). These perched levels store shallow polluted groundwater which percolates to deeper aquifer layers.

As reported by Reddy and DeLaune (2008) drainage conditions are reflected by the predominance of oxidized forms of nitrogen and sulphur (nitrate, sulphate). In general, the major fraction of soil OM is very insoluble and only a very little amount is leached towards the groundwater (Bohn et al., 2001). The main mechanism for soil OM removal is 
Héctor Aguilera y Luis Moreno Merino, 2019. Lessons learnt from semi-arid wetland... Boletín Geológico y Minero, 130 (4): $711-728$

oxidation through microbial degradation leading to increased acidity through decarbonation-carbonation reactions that is observed in the whole surface waterVZ-groundwater TDNP system. When moderate nitrate loadings enter the system, they can be managed by plants and microorganisms or retained by the soil matrix as $\mathrm{NH}_{4}{ }^{+}$, reducing the dissolved fraction that percolates towards the groundwater (Bohn et al., 2001). However, the cation exchange complex in dry TDNP peats is controlled by $\mathrm{Ca}^{2+}$ (JiménezPinilla, 2011), thus, large nitrate concentrations and infiltration rates observed in TDNP soils clearly pose a risk of groundwater pollution.

Soil and water nutrient overabundance allows the classification of the TDNP as a eutrophic system. In the case of the $P$ stored in organic soils, it is during the initial phases of the rewetting process when conditions are most favourable for its release as the system shifts to reducing conditions (Koerselman et al., 1993; Olila et al., 1997; Aldous et al., 2005; Niedermeier and Robinson, 2009). These conditions are also suitable for organic carbon and ammonia mobilization and subsequent risk of leaching towards the groundwater level (Zak and Gelbrecht, 2007). According to Koerselman et al. (1993), the release and mobilization of peat sorbed nutrients ( $N$ and $\mathrm{P}$ ), especially $\mathrm{P}$, are enhanced if the quality of flooding water is poor. In this sense, incoming waters through the Cigüela River or those usually pumped from the aquifer often have very low qualities. This issue is particularly relevant as the largest amounts of $P$ in the park accumulate in the fluvial silts of the ditch network which are connected to deeper aquifer layers.

Aldous et al. (2005) suggest maintaining soil saturated conditions to minimize the amount of $P$ released from recently rewetted wetland soils, whereas Olila et al. (1997) propose the addition of chemical amendments to counteract the initial release effect. Zak and Gelbrecht (2007) recommend the removal of the most decomposed peat layer to limit nutrient mobilization. However, topsoil removal does not seem advisable unless flooding is undertaken immediately and permanently (as has been the case in the TDNP for the past eight years). Furthermore, higher OM oxidation rates brought about by drainage conditions not only support the release of soil nutrients but also of $\mathrm{CO}_{2}$, thus contributing to the reversal of the function of the system function as a carbon sink (Rodríguez-Murillo et al., 2011; Sánchez-Andrés et al., 2010).

In a spatial context, a VZ chemical multivariate analysis identified three major soil environments in the TDNP: saline, organic (nutrients) and carbonated (Aguilera et al., 2011). A large percentage of the chem- ical variability was associated with four environmental factors (soil type, depth, microtopography and position regarding the central dam). These factors are susceptible to being altered by certain activities performed within the anthropic management of the wetland during drying periods such as the use of heavy farm machinery for reed reaping, cut-sedge sowing, construction of fire breaks, work for the extinction of peat fires, and artificial flooding with either groundwater or treated wastewater. The multivariate model associates saline soils (i.e. saline charophyte layers and clay) with higher topographical areas and the organic ones (i.e. fluvial silt and charophyte-peat alternations) with lower zones. Salinity and nutrients are more likely to accumulate upstream from the dam, whereas downstream the environment is dominated by carbonates (Aguilera et al., 2011). Edaphized charophytes accumulate higher amounts of soluble nutrients in the topsoil than fluvial silts.

Flooding with high salinity groundwater from emergency wells has been a usual practice during water shortage periods. The possibility of flooding a bigger area with treated wastewater during extremely dry periods is also considered in the REGATA plan (Sánchez-Carrillo et al., 2010). Both measures increase soil salinization and the above mentioned risk of nutrient mobilization through the VZ. At the same time, flooding with pumped groundwater is an expensive measure which also induces a local depletion of groundwater levels, thus, increasing the downward vertical hydraulic gradient (i.e. supporting infiltration and groundwater recirculation). However, from now on less saline groundwater will be used because there is a new emergency well field located further away from the TDNP flooded area (Fig. 1).

\section{Quantitative aspects}

The most relevant physical properties of dry TDNP soils indicate extremely high water transmissivity as shown by infiltration tests and saturated hydraulic conductivity determinations, particularly in organic SFT, in which lower bulk densities and higher OM contents determine a less compact structure (Aguilera et al., 2016). Saturated hydraulic conductivities $\left(\mathrm{K}_{\mathrm{s}}\right)$ calculated from infiltration tests on dry peat, peaty silt and edaphized charophytes are over $800 \mathrm{~cm}$ $\mathrm{d}^{-1}$, whereas average laboratory $\mathrm{K}_{\mathrm{s}}$ exceed $500 \mathrm{~cm} \mathrm{~d}^{-1}$ in all organic SFT, reaching up to over $4,000 \mathrm{~cm} \mathrm{~d}^{-1}$ and $22,000 \mathrm{~cm} \mathrm{~d}^{-1}$ in peaty silt and peat, respectively (Table 1). This is due to their highly developed secondary porosity upon shrinking and cracking caused by desiccation. In the case of peat, strong soil water 
repellency and limited wetting capacity worsens the negative hydraulic effect caused by drainage (i.e. soil physical degradation). Threshold values of $45 \%$ OM content and 9-22 vol\% critical soil water content range have been determined for soil water repellency development in TDNP peats. This means that peats with higher OM contents and/or with water contents below or within this range become water repellent. These facts condition that peat soils, in spite of showing the highest water retention properties, show lower water content than charophytes during a system dry out, as recorded by soil moisture sensors (Aguilera, 2013).

Implications of SFT physical characterization and spatial distribution during a drying period are discouraging. As stated above, average infiltration rates in the left-hand margin areas and downstream from the central dam increase several orders of magnitude compared to the values reported for flooded conditions (Castaño, 2004; Castaño et al., 2008; Navarro et al., 2011, 2012). High infiltration rates appear as the main cause for the sharp fluctuations observed in both flooding areas and groundwater levels, particularly in E-SE TDNP areas (García Rodríguez, 1996; Castaño, 2004; Aguilera et al., 2013; Castaño et al., 2012a,b). In situ field evidence of fast surface water loss was observed in 2008. Pumped groundwater poured over the peaty silts in the Guadiana ditch around the Molemocho dam (Fig. 1) infiltrated straight away and a sink-effect was observed in areas of preferential flow. The surface water-groundwater connection in the Guadiana ditch area has been corroborated by hydrochemical and isotopic analyses in surface water and groundwater (S5, S6 and G-08, Fig. 2).

On the other hand, the flooding area is not the only relevant feature regarding the quantitative state of the TDNP, which becomes the major concern for park managers. During drying periods, soil water content becomes the controlling factor for reed overgrowth and peat combustibility. The VZ water flow model presented in Aguilera et al. (2016) is a valuable management tool for hydrological planning in drought scenarios. For example, the TDNP managers could easily predict when critical soil water content for reed overgrowth or peat combustion risk would be reached under different climatic hypotheses once the flooded area has disappeared during a system dry out. Critical soil water contents in undisturbed charophytes and peat SFT were determined based on reference values of gravimetric and field capacity moistures found in the literature, and are reported in Aguilera et al. (2016). As models for the different SFT have already been calibrated and their parameters set, all that is needed to carry out simulations is a series of basic daily meteorological data (with rainfall amounts and minimum, mean and maximum temperatures being the minimum required). Simulations of a typical 2year drought scenario in the region indicated that critical soil moisture conditions for reed overgrowth are attained 9-10 months after flooding ceased and that peat areas colonized by reed plants become combustible (even $50 \%$ probability chance) by the end of the simulated period (Aguilera et al., 2016).

The diagram in Figure 3 shows how this tool can be implemented to support management and decision

\begin{tabular}{|c|c|c|c|c|c|c|c|c|c|}
\hline Soil type & $\begin{array}{c}\mathbf{B D} \\
\left(\mathbf{g} \mathbf{~ c m}^{-3}\right)\end{array}$ & $\begin{array}{c}\mathbf{K}_{\mathbf{s}} \mathbf{l a b} \\
\left(\mathbf{c m ~ d}^{-1}\right)\end{array}$ & $\begin{array}{c}\mathbf{K}_{\mathbf{s}} \text { infiltration } \\
\left(\mathbf{c m} \mathbf{d}^{-1}\right)\end{array}$ & $\begin{array}{c}\mathbf{O M} \\
(\%)\end{array}$ & $\begin{array}{c}\text { Sand } \\
(\%)\end{array}$ & $\begin{array}{c}\text { Silt } \\
(\%)\end{array}$ & $\begin{array}{c}\text { Clay } \\
(\%)\end{array}$ & $\begin{array}{c}\text { Texture } \\
\text { repellency }\end{array}$ \\
\hline Undisturbed charophytes & $0.76(0.14)$ & $84(11)$ & $171(126)$ & 6.0 & 34 & 57.7 & 8.3 & Silt loam & No \\
\hline Edaphized charophytes & $0.66(0.05)$ & $527(263)$ & $826(378)$ & 12.0 & 52.9 & 39.2 & 7.9 & Sandy Loam & Yes \\
\hline Saline charophytes & 0.56 & $1687(942)$ & - & 2.1 & 26.1 & 67.9 & 6 & Silt loam & No \\
\hline Clay & $1.30(0.09)$ & $148(17)$ & $99(105)$ & 3.5 & 12.3 & 68.1 & 19.6 & Silt loam & No \\
\hline Silt & $0.91(0.30)$ & $38(2)$ & $292(128)$ & 9.5 & 17.6 & 67.9 & 14.5 & Silt loam & No \\
\hline Peat & $0.18(0.04)$ & $22161(9009)$ & $996(149)$ & 50.1 & 88.1 & 0.0 & 11.9 & Loamy sand & Yes \\
\hline Organic & $0.52(0.06)$ & $588(176)$ & - & 33.0 & - & - & - & - & No \\
\hline Peaty silt & $0.77(0.02)$ & $4664(2560)$ & $857(525)$ & 53.1 & 15.1 & 61 & 23.9 & Silt loam & No \\
\hline
\end{tabular}

Table 1. Main average physical properties of soil functional types in the Tablas de Daimiel National Park. BD: bulk density; $K_{s}$ : saturated hydraulic conductivity both measured in the laboratory as well as estimated from infiltration tests: OM: organic matter. Values in brackets represent standard deviations.

Tabla 1. Valores medios y desviaciones estándar (entre paréntesis) de las propiedades físicas de los tipos funcionales de suelo en el Parque Nacional de Las Tablas de Daimiel. BD: densidad aparente; $\mathrm{K}_{\mathrm{s}}$ : conductividad hidráulica saturada medida en laboratorio y estimada a partir de ensayos de infiltración; OM: materia orgánica. 
making. In this way, management actions could be less dependent on improvisation and their impact on the physical system minimized. The modelling approach needs to be complemented with a monitoring network of soil moisture and temperature sensors at different depths as well as groundwater monitoring points, keeping track of events and/or predictions related to simulations as a feedback process for model improvement and update. Real-time monitoring in these points can help to detect and track the development of cracks and hollows as well as the effect of water inputs. Location of sampling points should be planned on the basis of the SFT map in targeted areas (Fig. 2). The combined monitoring-simulation process is then used to predict time patterns for the development of critical soil moisture conditions and support decision-making. The tool helps to decide the right time to undertake emergency measures, thus avoiding negative secondary effects such as groundwater pollution in the left-handTDNP margin area.

\section{Hydrological aspects}

A new permanent dam was built in the Cigüela ditch in the northern inlet area in 2012 and a temporary artificial "recharge pond" was also built in the Guadiana riverbed in 2013. This means that now the wholeTDNP is closed, as all inlet and outlet points are dammed. When the TDNP is flooded, the area becomes a system of connected reservoirs where hydrological conditions are artificially regulated (Castaño et al., 2012b). Upon drainage, the TDNP fully operates as an artificial recharge system with optimal performance in the left-hand margin area as a consequence of higher permeability of underlying materials and increased hydraulic gradients supported by higher pumping rates (Aguilera et al., 2013). Dam-closing conditions internal nutrient and OM accumulation (Sánchez-Carrillo and Álvarez-Cobelas, 2001; Sánchez-Carrillo et al., 2001). Considering that the system also receives wastewater inflows (Fig. 2), the

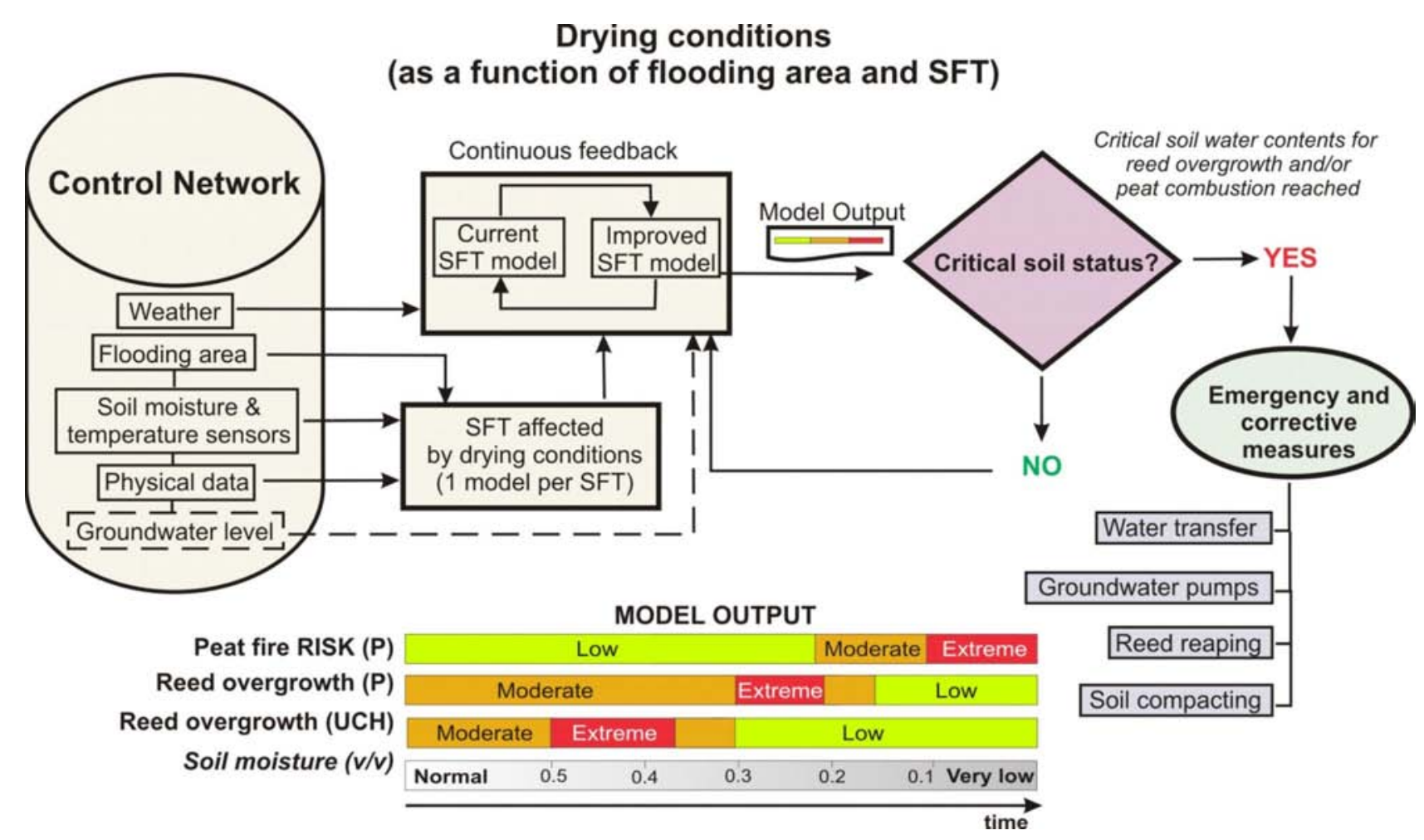

Figure 3. Diagram of soil moisture model implementation as a support tool for the Tablas de Daimiel National Park management during a drying period (Aguilera et al., 2016). The model allows the optimization of emergency and corrective measures (water transfers, pumps, etc.) to avoid reed overgrowth and cut-sedge disappearance, as well as the occurrence of smouldering peat fires. SFT: soil functional types; P: peat; UCH: undisturbed charophytes.

Figura 3. Esquema del funcionamiento de un modelo de humedad del suelo empleado como herramienta de gestión del Parque Nacional de Las Tablas de Daimiel en periodo de sequía (Aguilera et al., 2016). El modelo permite optimizar las medidas correctoras y paliativas (trasvases, bombeos, etc.) con el fin de evitar la invasión por parte del carrizo y la desaparición de la masiega, así como la aparición de incendios latentes. SFT: tipos funcionales de suelo; P: turba; UCH: caráceas no alteradas. 
functioning of the TDNP can be compared to that of a constructed wetland for wastewater treatment.

The hydrochemical, hydrodynamic and isotopic analyses leading to the conceptual model of SW-GW interactions presented in Aguilera et al. (2013) show the dynamic behaviour of the system in the left-hand margin of the TDNP (Fig. 4). Under natural conditions (A), all the layers of the multi-layer aquifer system would be saturated and the regional aquifer would discharge good quality groundwater into the TDNP wetland area.

During drying periods ( $B$ and $C$ ), drainage of overlaying highly permeable aquifer layers (i.e. karstified limestone) through semi-permeable materials, and increased pumping from emergency (in the TDNP) and irrigation wells (in eastern areas), promote sharp drawdowns of groundwater levels and separation of different aquifer levels through semi-permeable aquitards (Castaño et al., 2013). Hence, the regional flow is somehow disconnected from the local recharge flow and is likely to be predominantly horizontal towards the main pumping irrigation areas in the SE and SW. A big impoverishment of groundwater quality in the top layers occurs due to management practices and lithology (B), as low-quality artificially-maintained ponding water (i.e. pumped groundwater, water transfers) infiltrates through the saline nutrient rich sediments mentioned in the first

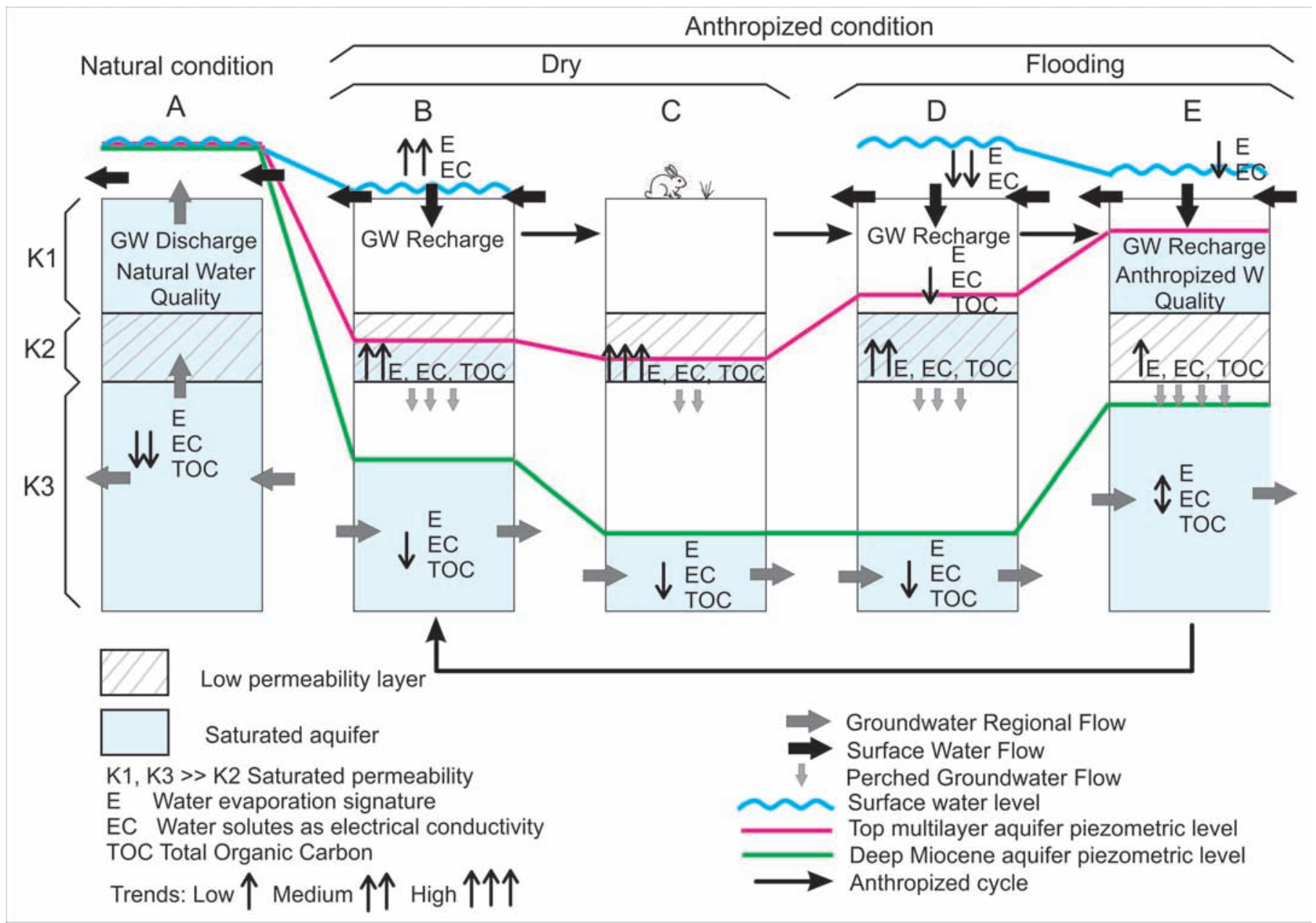

Figure 4. Schematic conceptual diagram of the surface water - groundwater interactions through the multi-layer aquifer system in the lefthand margin area of the Tablas de Daimiel National Park under natural and anthropized conditions during drying and re-flooding events (Aguilera et al., 2013). See the text for further discussion of the different stages A-E.

Figura 4. Esquema de la relación aguas superficiales - aguas subterráneas a través del acuífero multicapa en la margen izquierda del Parque Nacional de Las Tablas de Daimel Par la zona no saturada en la zona inundable del Parque Nacional de Las Tablas de Daimel en condiciones naturales y en condiciones antropizadas, tanto en periodo de inundación como en periodo de sequía (Aguilera et al., 2013). En el texto se ofrece información detallada de las etapas A-E. 
subsection. A slow percolation through semi-permeable layers is developed towards deeper more permeable levels connected to the regional flow (Castaño et al., 2013). Over time, due to the water exchange between the surface and subsurface, the layer with originally high quality fresh groundwater near the top of the aquifer is progressively replaced by contaminated water from the surface (C). It is uncertain how long contaminants are stored in groundwater before being transformed or discharged back.

Subsequent flooding events with low electrical conductivity surface water cause fast infiltration and re-saturation of the top karstified permeable layers, displacing the stored poor quality groundwater (D). At some point all the aquifer layers might also be re-saturated, conditioning groundwater mixing (E) and, upon subsequent drying, the risk of water and solute transport towards pumping areas.

The combination of high nutrient and OM content in both surface water and soil with high water transmissivity capacity in the VZ of the left-handTDNP margin condition groundwater pollution. Management actions (soil compacted by heavy machinery, recirculation of low quality groundwater, reed reaps, water transfers or smouldering fire extinction) increase the risk of releasing stored nutrients. As organic soils are widespread in the left-handTDNP margin area (Fig. 2), it is likely that increased SW-GW interactions in this area are powered by soil physical degradation. The entrance of heavy machinery in the TDNP should be restricted and their tracks controlled, as they mainly operate in these left-hand margin areas. Tractors modify the physical (i.e. structure, compaction) and geomorphological properties (i.e. microtopography) of soils as well as the nutrient balance. Although soil compacting may reduce infiltration rates, the random activity and the disruption of the soil structure leads to the development of new preferential flow paths for water and solutes. Furthermore, the removal of reed cover could accelerate the physical degradation of the soil due to increased soil exposure and decreased root system bonding effect.

But some questions remain: what amount of nutrients can be released in the VZ? How fast? Further analysis need to be carried out to answer these questions.

As pointed out by the results in our studies and argued by other authors, the lack of dynamic surfacesubsurface interaction (Harvey et al., 2007; Sophocleous, 2002; Kazezyilmaz-Alhan et al., 2007; Jolly et al., 2008) and distributed spatial considerations (Carol et al., 2011; Krause and Bronstert, 2004), might pose a serious source of error and uncertainty to existing hydrological models of the TDNP (EPTISA, 1986; García Rodríguez, 1996; Sánchez-Carrillo and Álvarez-Cobelas, 2010; Navarro et al., 2011). Furthermore, the spatial and temporal variability of the hydrological parameters is, in turn, the crucial information park managers need (Hughes et al., 2010).

When some key features such as geology or hydrogeology still remain partially unknown, the development of simple conceptual models of hydrological behaviour based on basic information (i.e. flooding area, groundwater levels and basic hydrochemical information), might be appropriate to determine specific areas or variables which need to be accurately studied and monitored in order to develop a reliable quantitative management tool (Hughes et al., 2010; Larsen et al., 2007; Patten et al., 2008). Therefore, for any future hydrological modelling of the TDNP aimed at supporting management practices the outcome of the conceptual model we present should be taken into account. The relative simplicity of this methodology allows for its application in other similar complex groundwater linked wetlands in semi-arid areas where detailed knowledge of local geology is still absent, as long as sufficient basic data and monitoring are available.

\section{Final synthesis}

Currently (December 2017), the TDNP has remained flooded for eight years. Flooding is now supported by both surface water as well as groundwater inflows. The prolonged hydroperiod has led to the rebirth of the so-called "Ojillos" springs along the Guadiana River, which had been dry since the 1980 s causing, for the first time in almost 30 years, groundwater discharge inflow. However, the ecological health of the ecosystem has not yet recovered. Recent studies highlight invasive species (Laguna et al., 2016) and chemical pollution (Jiménez-Ballesta et al., 2017; Rivetti et al., 2017) as the main factors for the loss of biodiversity. Moreover, Castaño et al. (2018) reported that although aquifer discharge took place continuously between 2012 and 2014, water quality is more saline than under natural conditions. Moreover, poorly treated wastewater discharges from the nearby towns of Villarrubia de los Ojos, Daimiel and Manzanares that end up in the Cigüela and Guadiana rivers have become a source of trace metal elements and other micro-pollutants such as endocrine-disruptors and dioxins.

On the other hand, water retention within the TDNP is regulated by a system of dams. The closing 
effect of the dams conditions the functioning of the system as an "artificial recharge pond" with the overall effect of solute accumulation (Aguilera et al., 2011; Jiménez-Ballesta et al., 2017). Laguna et al. (2016) suggest that this "dam" management is leading to ecological disturbances such as a massive increase in the population of invasive carp which have brought about a decline in the sub-aquatic Chara spp. meadows (the main food supply for herbivorous waterfowl species).

The circumstances mentioned above regarding wetland re-flooding connect with the conceptual model inferred from the findings of our research under drying conditions. The ecological status of the park is irreversible; degradation has altered the site to a point where complete denaturalization has been reached. Artificial management has turned the TDNP into what Wang et al. (2010) call an "anthropogenic wetland", completely dependent on human intervention. The lack of continuity between the wetland and the saturated zone makes recovery of the TDNP to its natural state quite difficult, at least on a human time scale. This has been evidenced by the lack of biodiversity recovery since the last re-flooding event in 2010 (Rivetti et al., 2017; Jiménez-Ballesta et al., 2017; Laguna et al., 2016). Climate change will further increase uncertainty regarding rehabilitation outcomes (Harris et al., 2006), particularly considering the increased aridity predicted for the Mediterranean region (Gao and Giorgi, 2008; Abouabdillah et al., 2010; IPCC, 2014).

During drying periods, the combination of large nutrient and OM content in surface water and soil with high water transmissivity capacities in the VZ of the left-hand TDNP margin, conditions groundwater pollution, as inferred from hydrological and hydrochemical analyses. The anthropic management of the TDNP (soil compacted by heavy machinery, recirculation of low quality groundwater, reed reaping, water transfers and smouldering fire extinction) increases the risk of releasing stored nutrients. As organic soils are widespread in the left-hand TDNP margin area, it is likely that increased SW-GW interactions in this area are enhanced by soil physical degradation.

Preferential flow paths through peat cracks and hollows in the $S$ and SE areas constitute freeways for water and solute transport (Moreno et al., 2010; Aguilera et al., 2013). Fluvial silts in ditches, which store large amounts of nutrients and $\mathrm{OM}$, as well as low permeability Tertiary levels, hold perched poorquality groundwater levels connected to deeper layers. The closing effect of the dams and the functioning of the system as an artificial recharge pond causes the overall effect of management measures during drying periods to be solute accumulation in the VZ. Thus, the chemical quality of soil and water is deteriorated and system salinization and eutrophication is enhanced. Moreover, the extent of SW-GW interactions condition a higher risk that groundwater pollution spreads through the groundwater flow that percolates from the TDNP to deeper aquifer layers and meets the regional flow towards pumping irrigation areas.

Increased understanding of the TDNP physicalchemical environment has allowed for the development of tools to support management of the park during a system dry out. The classification and mapping of SFT involves an enhancement of current knowledge of the physical environment and will contribute to the planning of management actions. It has allowed the delimitation of areas showing homogeneous behaviour and, thus, modelling times as well as monitoring systems costs can be optimized.

Vadose zone water flow simulations under different management scenarios can, for example, help to foresee the development of soil moisture conditions suitable for reed overgrowth and peat combustion risk (Fig. 3). The output of the unsaturated flow model could be also coupled to nutrient transport models.

The huge amount of compiled data on soil-water physical-chemical properties can be used to analyse medium and long term damage of drought and smouldering fires on the TDNP environment. It is also a baseline for eco-hydrological modelling approaches suitable for managing needs or for assessing the impact of climate change in arid and semi-arid wetlands.

Finally, although the impact derived from system management has been evidenced, there is still a need to quantify its influence and degree of disturbance on soil-water physical-chemical properties. Hopefully, the information provided in this research will contribute to support and enhance management actions in the Tablas de Daimiel National Park.

Further research on local geological characteristics (i.e. geophysical studies) and hydrological and hydrochemical dynamics in flooding periods is still required in order to build more accurate flux and transport hydrological models. It is crucial to develop a detailed 3D hydrogeological map, especially from the eastern side, to thoroughly assess the dynamics of the multilayer aquifer. The use of tracers and remote sensing to delimit hydrogeological compartments and connectivity is also advisable (Melendez-Pastor et al., 2010; Powell et al., 2008). A first approximation was made to characterize the physical properties of the TDNP peat, but research is still needed to accurately measure specific shrinking and hydraulic characteristics based on OM origin and composition as well as 
the degree of decomposition. Nevertheless, there is still a generalized lack of knowledge of Mediterranean semi-arid peatlands as inferred from the reviewed literature.

\section{Acknowledgements}

The data for this paper can be made available upon request to the corresponding author. This research was financed by the State Secretariat for Research, Development and Innovation through the CICYT projects

CGL2005-06458-C02-01 and CGL2009-13507. Special thanks must be given to the IGME staff and to the Tablas de Daimiel National Park Management for the provided data and all the facilities and support for access and sampling. Analytical determinations have been carried out at the Soil Science Department of the Complutense University of Madrid, at the Soil Science Centre of the Alterra Research Institute of Wageningen UR and at IGME laboratories.

\section{References}

Abouabdillah, A., Oueslati, O., De Girolamo, A.M. and Porto, A.L. 2010. Modeling the impact of climate change in a mediterranean catchment (Merguellil, Tunisia). Fresenius Environmental Bulletin, 59, 2334-2347.

Aguilera, H., Castaño, S., Moreno, L., Jiménez-Hernández, M.E. and de la Losa, A. 2013. Model of hydrological behaviour of the anthropized semiarid wetland of Las Tablas de Daimiel National Park (Spain) based on surface water-groundwater interactions. Hydrogeology Journal, 21, 623-641.

Aguilera, H. 2013. Soil-Water system response in an anthropized Mediterranean wetland during drying cycles: Las Tablas de Daimiel National Park. Ph.D. thesis, Universidad Complutense de Madrid, 306 pp.

Aguilera, H., Moreno, L., Jiménez-Hernández, M.E., Castaño, S. and de la Losa, A. 2011. Management implications inferred from the multivariate analysis of vadose zone chemical variables in Las Tablas de Daimiel National Park (Spain). Geoderma, 162, 365-377.

Aguilera, H., Moreno, L., Wesseling, J.G., JiménezHernández, M.E. and Castaño, S. 2016. Soil moisture prediction to support management in semiarid wetlands during drying episodes. Catena, 147, 709-724.

Aldous, A., McCormick, P., Ferguson, C., Graham, S. and Craft, C. 2005. Hydrologic regime controls soil phosphorus fluxes in restoration and undisturbed wetlands. Restoration Ecology, 13 (2), 341-347.

Álvarez-Cobelas, M., Cirujano, S., Sánchez-Carrillo, S. 2001. Hydrological and botanical man-made changes in the Spanish wetland of Las Tablas de Daimiel. Biological Conservation, 97, 89-98.
Amezaga, J.M. and Santamaría, L. 2000. Wetland Connectedness and Policy Fragmentation: Steps Towards a Sustainable European Wetland Policy. Physics and Chemistry of the Earth (B), 25, 635-640.

Bohn, H.L., McNeal, B.L. and O'Connor, G.A. 2001. Soil chemistry. 3rd ed. John Wiley \& Sons, Inc, New York, 307 pp.

Carol, E.S., Kruse, E.E. and Pousa, J.L. 2011. Influence of the geologic and geomorphologic characteristics and of crab burrows on the interrelation between surface water and groundwater in an estuarine coastal wetland. Journal of Hydrology, 403, 234-241.

Castaño, S. 2004. Estudio metodológico para el cálculo de la infiltración en el vaso de las Tablas de Daimiel: validación de resultados. Ph.D. thesis, Universidad Complutense de Madrid, $112 \mathrm{pp}$.

Castaño, S., Martínez-Santos, P. and Martínez-Alfaro, P.E. 2008. Evaluating infiltration losses in a Mediterranean wetland: Las Tablas de Daimiel National Park, Spain. Hydrological Processes, 22, 5048-5053.

Castaño, S., Moreno, L., Aguilera, H., de la Losa, A. and Jiménez-Hernández, M.E. 2012a. Las aguas subrerráneas en el entorno del Parque Nacional de Las Tablas de Daimiel. In: Mediavilla, R. (ed.), Las Tablas de Daimiel: agua y sedimentos. Medio Ambiente Series, 14. Instituto Geológico y Minero de España, Madrid, 59-86

Castaño, S., Moreno, L., Aguilera, H., de la Losa, A. and Jiménez-Hernández, M.E. 2012b. Antropización del Parque Nacional de Daimiel: una visión desde la perspectiva del ciclo hídrico. In: Mediavilla, R. (ed.), Las Tablas de Daimiel: agua y sedimentos. Medio Ambiente, 14. Instituto Geológico y Minero de España, Madrid, 259-269.

Castaño, S., Mediavilla, R., Santisteban, J.I., de la Losa, A. and Martínez-Santos, P. 2013. Aportación al conocimiento del comportamiento hidrogeológico del límite Terciario-Cuaternario en el entorno del Parque Nacional de las Tablas de Daimiel. Geogaceta, 54, 111-114.

Castaño, S., de la Losa, A., Martínez Santos, P., Mediavilla, R. and Santisteban, J.I. 2018. Long term effects of aquifer overdraft and recovery on groundwater quality in a Ramsar wetland: Las Tablas de Daimiel National Park, Spain. Hydrological Processes, 32 (18), 2863-2873.

Cirujano, S., Álvarez-Cobelas, M. and Ruíz de la Hermosa, C. 2010. Analysis of applied environmental management strategies for wetland conservation during the last 30 years: a local history. Sánchez-Carrillo, S., Angeler, D.G. (eds.), Ecology of Threatened Semi-Arid Wetlands: LongTerm Research in Las Tablas de Daimiel. Springer Science+Business Media B.V., 229-237.

Centro Nacional de Información Geográfica (CNIG), 27/12/2017, http://centrodedescargas.cnig.es

DeBano, L.F. 2000. The role of fire and soil heating on water repellency in wildland environments: a review. Journal of Hydrology, 231-232, 195-206.

del PozoTejado, J. and Mejías Moreno, M. 2017. Los Ojos del Guadiana y del Gigüela: el resurgir de una masa de agua subterránea declarada "en riesgo". Boletín Geológico y Minero, 128 (4), 885-911.

Dikici, H. and Yilmaz, C.H. 2006. Peat fire effects on some 
properties of an artificially drained peatland. Journal of Environmental Quality, 35, 866-870.

Doerr, S.H., Shakesby R. and Walsh, R.P.D. 2000. Soil water repellency: its causes, characteristics and hydro-geomorphological significance. Earth-Science Reviews, 51, 33-65.

Domínguez-Castro, F., Santisteban, J.I., Mediavilla, R., Dean, W.E., López-Pamo, E., Gil-García, M.J. and Ruiz-Zapata, M.B. 2006. Environmental and geochemical record of human-induced changes in $\mathrm{C}$ storage during the last millennium in a temperate wetland (Las Tablas de Daimiel National Park, central Spain). Tellus, 58, 573-585.

Engloner, A.l. 2009. Structure, growth dynamics and biomass of reed (Phragmites australis) - A review. Flora, 204, 331-346.

EPTISA 1986. Estudio de viabilidad de un Plan de regeneración hídrica en el Parque Nacional de las Tablas de Daimiel. Tomo I. Memoria. Informe inédito, 102 págs.

Fox DM, Darboux F, Carrega P (2007) Effects of fire-induced water repellency on soil aggregate stability, splash erosion, and saturated hydraulic conductivity for different size fractions. Hydrol Process 21:2377-2384

Gao, X. and Giorgi, F. 2008. Increased aridity in the Mediterranean region under greenhouse gas forcing estimated from high resolution simulations with a regional climate model. Global and Planetary Change, 62, 195-209.

García Rodríguez, M. 1996. Hidrogeología de las Tablas de Daimiel y de los ojos del Guadiana: bases hidrogeológicas para una clasificación funcional de humedales ribereños. Ph.D. thesis, Universidad Complutense de Madrid, 406 pp.

García-Hidalgo, J.F., Temiño, J., de Bustamante, I. and Segura, M. 1995. Evolución sedimentaria reciente de las Tablas de Daimiel (Ciudad Real). Geogaceta, 18, 87-89.

Giovannini, G. and Lucchesi, S. 1997. Modifications induced in soil physico-chemical parameters by experimental fires at different intensities. Soil Science, 162 (7), 479486.

Harris, J.A., Hobbs, R.J., Higgs, E. and Aronson, J. 2006. Ecological restoration and global climate change. Restoration Ecology, 14, 170-176.

Harvey, F.E., Ayers, J.F. and Gosselin, D.C. 2007. Ground water dependence of endangered ecosystems: Nebraska's eastern saline wetlands. Ground water, 45, 736-752.

Harvey, J.W. and McCormick, P.V. 2009. Groundwater's significance to changing hydrology, water chemistry, and biological communities of a floodplain ecosystem, Everglades, South Florida, USA. Hydrogeol Journal, 17, 185-201.

Hattermann, F.F., Krysanova, V. and Hesse, C. 2008. Modelling wetland processes in regional applications. Hydrological Sciences Journal, 53, 1001-1012.

Hughes, D.A., Kapangaziwiri, E. and Baker, K. 2010. Initial evaluation of a simple coupled surface and ground water hydrological model to assess sustainable ground water abstractions at the regional scale. Hydrology Research, 41, 1-12.

IPCC 2014. Climate Change 2014: Synthesis Report. Contribution of Working Groups I, II and III to the Fifth
Assessment Report of the Intergovernmental Panel on Climate Change [Core Writing Team, R.K. Pachauri and L.A. Meyer (eds.)]. IPCC, Geneva, Switzerland, 151 págs. Jia, Z. and Luo, W. 2009. A modified climate diagram displaying net water requirements of wetlands in arid and semi-arid regions. Agricultural Water Management, 96, 1339-1343.

Jiménez-Ballesta, R., García-Navarro, F.J., Bravo, S., Amorós, J.A., Pérez-de-los-Reyes, C. and Mejías M. 2017. Environmental assessment of potential toxic trace element contents in the inundated floodplain area of Tablas de Daimiel wetland (Spain). Environmental Geochemistry and Health, 39 (5), 1159-1177.

Jiménez-Pinilla, P. 2011. Estudio de las turbas en el Parque Nacional de Las Tablas de Daimiel. EAE Editorial Académica Española, 104 pp.

Johnston, C.A. 1994. Cumulative impacts to wetlands. Wetlands, 14, 49-55.

Jolly, I.D., McEwan, K.L. and Holland, K.L. 2008. A review of groundwater-surface water interactions in arid/semi-arid wetlands and the consequences of salinity for wetland ecology. Ecohydrology, 1, 43-58.

Kazezyilmaz-Alhan, C.M., Medina, M.A. and Richardson, C.J. 2007. A wetland hydrology and water quality model incorporating surface water/groundwater interactions. Water Resources Research, 43(4), W04434.

Koerselman, W., Van Kerkhoven, M. and Verhoeven, J. 1993. Release of inorganic N, P and K in peat soils; effect of temperature, water chemistry and water level. Biogeochemistry, 20, 63-81.

Krause, S. and Bronstert, A. 2004. Approximation of Groundwater - Surface Water - Interactions in a Mesoscale Lowland River Catchment. Hydrology: Science \& Practice for the 21st Century. Volume II, British Hydrological Society, 408-415.

Krause, S., Heathwaite, A.L., Miller, F., Hulme, P. and Crowe, A. 2007. Groundwater-Dependent Wetlands in the UK and Ireland: Controls, Functioning and Assessing the Likelihood of Damage from Human Activities. Water Resources Management, 21, 2015-2025.

Laguna, C., López-Perea, J.J., Viñuela, J., Florín, M., Feliu, J., Chicote, Á., Cirujano, S. and Mateo, R. 2016. Effects of invasive fish and quality of water and sediment on macrophytes biomass, and their consequences for the waterbird community of a Mediterranean floodplain. Science of the Total Environment, 551-552, 513-521.

Larsen, L.G., Harvye, J.W. and Crimaldi, J.P. 2007. A delicate balance: ecohydrological feedbacks governing landscape morphology in a lotic peatland. Ecological Monographs, 77, 591-614.

Litaor, M.I., Eshel, G., Reichmann, O. and Shenker, M. 2006. Hydrological Control of Phosphorus Mobility in Altered Wetland Soils. Soil Science Society of America Journal, 70, 1975-1982.

Manzano, M., Borja, F. and Montes, C. 2002. Metodología de tipificación hidrológica de los humedales españoles con vistas a su valoración funcional y a su gestión. Aplicación a los humedales de Doñana. Boletín Geológico y Minero, 113, 313-330. 
Martínez-Santos, P., de Stefano, L., Llamas, M.R. and Martínez-Alfaro, P.E. 2008a. Wetland Restoration in the Mancha Occidental Aquifer, Spain: A Critical Perspective on Water, Agricultural, and Environmental Policies. Restoration EcologyK, 16, 511-521.

Martínez-Santos, P., Llamas, M.R., Martínez-Alfaro, P.E. 2008b. Vulnerability assessment of groundwater resources: A modelling-based approach to the Mancha Occidental aquifer, Spain. Environmental Modelling \& Software, 23, 1145-1162.

Melendez-Pastor, I., Navarro-Pedreño, J., Gómez, I. and Koch, M. 2010. Detecting drought induced environmental changes in a Mediterranean wetland by remote sensing. Applied Geography, 30, 254-262.

Mesnage, V., Bonneville, S., Laignel, B., Lefebvre, D., Dupont, J.P. and Mikes, D. 2002. Filling of a wetland (Seine estuary, France): natural eutrophication or anthropogenic process? A sedimentological and geochemical study of wetland organic sediments. Hydrobiologia, 475-476, 423-435.

Messerli, B., Grosjean, M., Hofer,T., Núñez, L. and Pfister, C. 2000. From nature-dominated to human-dominated environmental changes. Quaternary Science Reviews, 19, 459-479.

Mitsch, W.J. and Gosselink, J.G. 2000. Wetlands. Wiley, New York, 920 pp.

Moiwo, J.P., Lu, W., Zhao, Y., Yang, Y. and Yang, Y. 2010. Impact of land use on distributed hydrological processes in the semi-arid wetland ecosystem of Western Jilin. Hydrological Processes, 24, 492-503.

Moreno, L., de la Losa, A., Jiménez-Hernández, M.E., Aguilera, H. and Castaño, S. 2013. Influencia del zanjón del río Cigüela sobre el humedal del Parque Nacional de as Tablas de Daimiel (España) en periodo de sequía. Cuaternario y Geomorfología, 27 (1-2), 111-128.

Moreno, L., Jiménez-Hernández, M.E., Aguilera, H., Jiménez, P. and de la Losa, A. 2010. The 2009 Smouldering Peat Fire in Las Tablas de Daimiel National Park (Spain). Fire Technology, 47, 519-538.

Navarro, V., García, B. and Asensio, L. 2012. Characterization of the infiltration rate in Las Tablas de Daimiel National Park, Central Spain. Hydrological Processes, 26, 367-378.

Navarro, V., García, B., Sánchez, D. and Asensio, L. 2011. An evaluation of the application of treated sewage effluents in Las Tablas de Daimiel National Park, Central Spain. Journal of Hydrology, 401, 53-64.

Niedermeier, A. and Robinson, J.S. 2007. Hydrological controls on soil redox dynamics in a peat-based, restored wetland. Geoderma, 137, 318-326.

Niedermeier, A. and Robinson, J.S. 2009. Phosphorus dynamics in the ditch system of a restored peat wetland. Agriculture, Ecosystems \& Environment, 131 (3-4), 161169.

Olila, O.G., Reddy, K.R. and Suites, D.L. 1997. Influence of draining on soil phosphorus forms and distribution in a constructed wetland. Ecological Engineering, 9, 157-169.

Patten, D.T., Rouse, L. and Stromberg, J.C. 2008. Isolated spring wetlands in the Great Basin and Mojave deserts, USA: potential response of vegetation to groundwater withdrawal. Environmental Management, 41, 398-413.
Pfadenhauer, J. and KIötzli, F. 1996. Restoration experiments in middle European wet terrestrial ecosystems: an overview. Vegetatio, 126, 101-115.

Reddy, K.R. and DeLaune, R.D. 2008. Biogeochemistry of Wetlands: Science and Applications. CRC Press, Taylor \& Francis Group, New York, 800 pp.

Rein, G. 2009. Smouldering Combustion Phenomena in Science and Technology. International Review of Chemical Engineering, 1, 3-18.

Rein, G., Cleaver, N., Ashton, C., Pironi, P. and Torero, J.L. 2008. The severity of smouldering peat fires and damage to the forest soil. Catena, 74, 304-309.

Richter, B.D., Baumgartner, J.V., Powell, J. and Braun, D.P. 1996. A Method for Assessing Hydrologic Alteration within Ecosystems. Conservation Biology, 10, 1163-1174.

Rivetti, C., López-Perea, J.J., Laguna, C., Piña, B., Mateo, R., Eljarrat, E., Barceló, D. and Barata, C. 2017. Integrated environmental risk assessment of chemical pollution in a Mediterranean floodplain by combining chemical and biological methods. Science of the Total Environment, $583,248-256$.

Rodríguez-Murillo, J.C., Almendros, G. and Knicker, H. 2011. Wetland soil organic matter composition in a Mediterranean semiarid wetland (Las Tablas de Daimiel, Central Spain): Insight into different carbon sequestration pathways. Organic Geochemistry, 42, 762-773.

Rodríguez-Murillo, J.C., Almendros, G. and Knicker, H. 2017. Humic acid composition and humification processes in wetland soils of a Mediterranean semiarid wetland. Journal of Soils and Sediments, 17, 2104-2115.

Rudolph, D.L., Sultan, R., Garfias, J. and McLaren, R.G. 2005. Significance of enhanced infiltration due to groundwater extraction on the disappearance of a headwater lagoon system: Toluca Basin, Mexico. Hydrogeology Journal, 14, 115-130.

Sánchez-Andrés, R., Sánchez-Carrillo, S., Ortiz-Llorente, M.J., Álvarez-Cobelas, M. and Cirujano, S. 2010. Do changes in flood pulse duration disturb soil carbon dioxide emissions in semi-arid floodplains? Biogeochemistry, 101, 257-267.

Sánchez-Carrillo, S. and Álvarez-Cobelas, M. 2001. Nutrient dynamics and eutrophication patterns in a semi-arid wetland: the effects of fluctuating hydrology. Water, Air, \& Soil Pollution, 131, 97-118.

Sánchez-Carrillo, S. and Álvarez-Cobelas, M. 2010. Climate and Hydrologic Trends: Climate Change Versus Hydrologic Overexploitation as Determinants of the Fluctuating Wetland Hydrology. In: Sánchez-Carrillo, S., Angeler, D.G. (eds.,), Ecology of Threatened Semi-Arid Wetlands: Long-Term Research in Las Tablas de Daimiel. Springer Science+Business Media B.V., 45-83.

Sánchez-Carrillo, S., Álvarez-Cobelas, M. and Angeler, D.G. 2001. Sedimentation in the semi-arid freshwater wetland Las Tablas de Daimiel (Spain). Wetlands, 21, 112-124.

Sánchez-Carrillo, S., Angeler, D.G., Cirujano, S. and ÁlvarezCobelas, M. 2010. The wetland, its catchment settings and socioeconomic relevance: an overview. In: SánchezCarrillo, S., Angeler, D.G. (eds.), Ecology of Threatened Semi-Arid Wetlands: Long-Term Research in Las Tablas de Daimiel. Springer Science+Business Media B.V., 3-20. 
Sánchez-Carrillo, S., Angeler, D.G., Sánchez-Andrés, R., Álvarez-Cobelas, M. and Garatuza-Payán, J. 2004. Evapotranspiration in semi-arid wetlands: relationships between inundation and the macrophyte cover:openwater ratio. Advances in Water Resources, 27, 643-655.

Santisteban, J.I. and Mediavilla, R. 2012. Evolución de las temperaturas y las precipitaciones desde el siglo XIX (Temperature and precipitation patterns since the XIX century). In: Mediavilla, R. (ed.), Las Tablas de Daimiel: agua y sedimentos. Medio Ambiente Series, 14. Instituto Geológico y Minero de España, Madrid, 17-36.

Sikdar, P.K. and Sahu, P. 2009. Understanding wetland subsurface hydrology using geologic and isotopic signatures. Hydrology and Earth System Sciences, 13, 13131323.

Sophocleous, M. 2002. Interactions between groundwater and surface water: the state of the science. Hydrogeology Journal, 10, 52-67.

Sutula, M.A., Perez, B.C., Reyes, E., Childers, D.L., Davis, S., Day, J.W., Rudnick, D. and Sklar, F. 2003. Factors affecting spatial and temporal variability in material exchange between the Southern Everglades wetlands and Florida Bay (USA). Estuarine, Coastal and Shelf Science, 57, 757-781.

Thiere, G., Milenkovski, S., Lindgren, P-E, Sahlén, G., Berglund, O. and Weisner, S.E.B. 2009. Wetland creation in agricultural landscapes: Biodiversity benefits on local and regional scales. Biological Conservation, 142, 964973.

van Duren, I.C. and Pegtel, D.M. 2000. Nutrient limitations in wet, drained and rewetted fen meadows: evaluation of methods and results. Plant and Soil, 220, 35-47.

Wang, M., Qin, D., Lu, C. and Li, Y. 2010. Modeling Anthropogenic Impacts and Hydrological Processes on a Wetland in China. Water Resources Management, 24, 2743-2757.Zak, D. and Gelbrecht, J. 2007. The mobilisation of phosphorus, organic carbon and ammonium in the initial stage of fen rewetting (a case study from NE Germany). Biogeochemistry, 85, 141-151.

Zedler, J.B. 2000. Progress in wetland restoration ecology. Tree, 15, 402-407.

Zedler, J.B. and Kercher, S. 2005. Wetland Resources: Status, Trends, Ecosystem Services, and Restorability. Annual Review of Environment and Resources, 30, 3974.

Zorrilla, P., Carmona, G., De la Hera, Á., Varela-Ortega, C., Martínez-Santos, P., Bromley, J. and Jorgen Henriksen, H. 2010. Evaluation of bayesian networks as a tool for participatory water resources management: application to the Upper Guadiana basin in Spain. Ecology and Society, 15(3): 12.

Recibido: julio 2018

Revisado: septiembre 2018

Aceptado: febrero 2019

Publicado: diciembre 2019 